\author{
Anna ODROWĄŻ-COATES \\ Maria Grzegorzewska University in Warsaw \\ acoates@aps.edu.pl
}

\title{
CULTURAL CONDITIONING OF THE LABOUR MARKET IN SAUDI ARABIA
}

ABSTRACT The present work concerns an anthropological outlook on the political consequences of corporate and economic migration to the Kingdom of Saudi Arabia (KSA) and labour market segregation. The complexity of cultural codes and the clash of customs are discussed in the paper, which is based on a two-year period of sociological field research conducted in the KSA by the author. The ethnographic materials are enriched by discourse from daily Saudi papers and other international publications. The study contains an insight into race and ethnicity as seen by Saudis themselves and also allows a deeper understanding of the power distribution in this particular modern Islamic society. In the climate of the European economic crisis, the sustained demand for highly qualified migrant workers in the KSA provides a lucrative alternative for specialists across market sectors and this often involves their families. In light of the globalised market, many corporations run multi-billion dollar contracts inside the Kingdom and relocate their own work force to achieve business goals. The need for specialists and for cheap manual labour from abroad is a direct result of the Saudi education system, together with the work ethic amongst the majority of Saudi nationals, which is heavily influenced by the cultural and sociological consequences of the Wahhabi interpretation of the Quran. This interpretation has a major impact on Saudi society and on migrants, particularly women. The social order is widely supported and successfully reproduced through a united message present in education, the national media and local mosques. Concerns over ethnic divisions are focused on conflicting ideologies, represented in the interactions between newcomers and the indigenous population.

Keywords: ethnicity, class, labour market segregation, social order. 


\section{HISTORICAL ROOTS OF SOCIAL ORDER}

Saudi Arabia has been a religious state since 1927, adhering to Sharia laws and regulations. However, since the fall of the pro-western Iranian Shah, Mohammad Reza Pahlavi in 1979, the Saudi monarchy turned towards religious accreditation of their governance of the country by implementing the strict regulations required by Wahhabism. The Wahhabi interpretation of Sharia laws was one of many Sunni schools of Islamic thought within the Kingdom, but is now the dominant theology. On his succession to the throne, the current King, Abdullah, became the self-proclaimed 'Custodian of the Two Holy Mosques' in Makah and Medina, thus ensuring the religious endorsement of his reign. Wahhabism is a socio-political movement based on an austere religious interpretation of the Quran, initiated by Mohammed Ibn Abdul Wahhab, born in 1703/4 (1115 AH). He aimed to purify Islam by advocating increased self-discipline, prayer to the one and only God, and the prohibition of public entertainment and substances such as tobacco, alcohol or drugs, which in his opinion would lead to the moral downfall of society. ${ }^{1}$ This vision was revived by the blind Sheikh Abdul Aziz Ibn Baz in 1965 and then grew in power due to the Iranian revolution posing a threat to the house of Saud's absolute monarchy. ${ }^{2}$ Meanwhile, oil wealth allowed the country to flourish financially and therefore rapidly develop technologically. This created a paradox; On the one hand it gave rise to the skyscrapers, the latest hi-tech innovations, the most expensive cars and technologies which are now prevalent, on the other, there has been a great effort to obstruct western globalization with its unavoidable secular message.

The obstructive effort had a negative effect on the Saudi education system, where too much emphasis was put on theological study whilst the needs of the job market were completely ignored. ${ }^{3}$ Over 75 per cent of graduates who were seeking jobs labelled humanities or religious studies as their major. ${ }^{4}$ Local universities enforced Islamic education of students by running summer camps dedicated to religious study. ${ }^{5}$ Although the number of students has been rising since 1980, resources are still disproportionately allocated to religious universities and programs. ${ }^{6}$

1 M. Al-Rasheed, Contesting the Saudi State. Islamic Voices from a New Generation, Cambridge-New York 2007 (Cambridge Middle East Studies, 25)

2 R. Lacey, Inside the Kingdom. Kings, Clericis, Modernists, Terrorists and the Struggle for Saudi Arabia, London 2009.

3 M. Prokop, 'The War of Ideas: Education in Saudi Arabia' in P. Aarts, G. Nonneman (eds.), Saudi Arabia in the Balance. Political Economy, Society, Foreign Affairs, New York 2006.

4 G. Okruhlik, 'Networks of Dissent: Islamism and Reform in Saudi Arabia', Social Science Research Council, at <http://essays.ssrc.org/sept11/essays/okruhlik_text_only.htm>, 1 March 2013.

5 A. Al-Lheedan, Higher Education, Political Development and Stability in Saudi Arabia, Ph.D. dissertation, University of Southern California 1994, p. 210.

6 G.G. Gilbar, The Middle East Oil Decade and Beyond. Essays in Political Economy, London-Portland 1997, pp. 77-101; and N.I. Rashid, E.I. Shaheen, King Fahd and Saudi Arabia's Great Evolution, Joplin (Mo.) 1987, p. 123. 
This led to a growing number of unemployed and unemployable young graduates, which created a gap in the labour market that needed filling with specialist manpower from elsewhere. According to official Saudi statistics, 27 percent of Saudis under the age of 30 were unemployed in 2009..$^{7}$ This poses a challenge for the Saudi economy. It could be argued that the money invested in higher education has not increased the social capital of the country and has been a profligate investment causing a strain on the benefit system. One of the other major issues is that half of the population (Saudi women) is excluded from the labour market outside of the medical, care and teaching sectors (occupations that "suit" the female nature). The level of participation of women in the workforce is the lowest in the world; ${ }^{8}$ only $4-5 \%$ of Saudi women work. Women make up no more than 10 per cent of the Saudi workforce ${ }^{9}$ (It is not clear whether the figure includes foreign nannies and housekeepers). Married women are discouraged from working and there are many restrictions placed on women as a social group; the bans on driving or free movement without a guardian's permission are typical of the problems women face. Significantly lower levels of earnings may be a demotivating factor, coupled with the cultural need to strictly segregate the genders in public and the belief that a woman's place is at home with her family. Because of the risk of contact with unrelated males,working women may be seen as immoral and their marital choices may be compromised. Out of 124 Saudi women that were interviewed, almost 80 percent were convinced that it is a blessing not to have to work, not to have to drive and not worry about financial troubles. The remainder, however, did not agree with the restrictions placed on women and would welcome custom and legal changes in this matter. ${ }^{10}$

Wahhabism may be seen as responsible for Saudi Arabia's economic stagnation (in terms of the labour market) and some have said that it has led the kingdom into a vicious circle of isolation, slowing down the introduction of modernity. ${ }^{11}$

\section{CLASS DIVISION IN CONTEMPORARY SAUDI SOCIETY}

There is a visible class division within the indigenous population. At the top of the social hierarchy sit hundreds of princes and princesses from the Saudi Royal family. The direct descendents of the prophet Mohamed from the Quraysh and Hashimite

J. Sfakianakis, 'Banque Saudi Fransi: Saudi Arabia Economics - Employment Quandary', The Gulf Intelligence, 21 February 2011, at <http://www.thegulfintelligence.com/Docs.Viewer/8ad91021-1053-43d7-b8a8-d250151257ab/default.aspx>, 1 March 2013.

8 S. Marchand, Arabie Saoudite, la menace, Paris 2003.

9 M.S. Fakeeh, Saudization as a Solution for Unemployment. The Case of Jeddah Western Region, Doctoral Thesis in Business Administration, University of Glasgow 2009.

10 A. Odrowąż-Coates, Fatamorgana saudyjskiej przestrzeni spoteczno-kulturowej kobiet. Ptynne horyzonty socjalizacji, edukacji i emancypacji, Kraków 2015.

11 M. Ramady, The Saudi Arabian Economy. Policies, Achievements and Challenges. New York 2005; and M.S. Fakeeh, Saudization as a Solution... 
tribes also rank highly. One of the distinctive features that characterize the Saudi elites is the fairness of their skin. People of whiter skin colour are considered to be of higher class. The middle classes, who are mainly wealthy businessmen, the oil and construction "bourgeoisie", place the highest importance on the education of their children. They want to ensure that their heirs will be highly qualified and therefore secure in the future. They, like the upper classes, often send their children to universities and boarding schools abroad. ${ }^{12}$ Local clerics oppose this trend as it exposes young impressionable people to Western culture and customs, which are deemed immoral and in conflict with Saudi religious ideology. Study abroad programs had their funding removed in 1982 and temporary regulations prohibited female students from studying abroad at all. ${ }^{13}$ Moreover, new universities and colleges have sprung up at speed in an attempt to curb the Western influence on the young Saudi elites. This is also true for women, who are now allowed to study science in the country. This was not possible before, as the subject matter was perceived to be against the female nature and talents. King Abdullah University of Science and Technology is the first university that allows women to study alongside men. ${ }^{14}$

One can observe an immense gap between rich and poor. Working classes by definition are poor and struggle to maintain a good standard of life. It is visible that the majority of working-class people are of darker skin colour and of Arab descent, or are the descendents of African slaves. ${ }^{15}$ It is a common perception that people of darker skin colour are predestined to work in manual labour and to serve those whose skin colour is fairer. There is a definite glass ceiling for black people to obtain any position of power. In my 3 years in Saudi, working for the Air Force, I have only met one black officer in their military service, said one of 119 non-Saudi interviewees. ${ }^{16}$

Bedouin tribes are usually dark skinned and therefore, despite love for desert traditions are perceived as "worse," "badly educated," "poor and insignificant." However, this is counterbalanced by the King's own army, the National Guard, which is almost entirely made up of tribes that are considered loyal to the house of Saud. The Saudi National Guard was created as a personal defence force for the king but also serves as a conduit to engage, develop and educate tribal people, as well as keeping them "in check". Modern, clean, bright and anything but tribal, hospitals and schools with active adult education units expanded throughout the country. ${ }^{17}$ Beginning in 1985, the Saudi National Guard sponsored the "Janadiriyah" festival that institutionalized traditional folk dances, camel races and tribal heritage, allowing for public entertainment,

12 S. Marchand, Arabie Saoudite...

13 A. Vassiliev, The History of Saudi Arabia, London 2000, p. 397.

14 King Abdullah University of Science and Technology, at <http://www.kaust.edu.sa/>, 3 March 2013.

15 Slavery in Saudi Arabia was abolished in 1962 but is still considered by many as an act permissible in the Quran.

16 A. Odrowąż-Coates, 'Gated Community as a "Soft" and Gendered Total Institution', International Sociology, Vol. 30, No. 3 (2015), pp. 233-249, at <http://dx.doi.org/10.1177/0268580915578759>.

17 R. Lacey, Inside the Kingdom..., pp. 184-185. 
which had previously been condemned by Wahhabist views. ${ }^{18}$ The feudal tradition of the client - patron relationship between monarch and tribes, sealed by the marriages of Abdulaziz with 22 women from the most significant clans, has been continued by his successors with similarly strategic matrimonies, thus cementing the relationships with prominent families.

Saudis do have some interesting ideas about skin colour that can be translated into an indigenous discourse of whiteness. A large group of Saudi women said that they thought Europeans and Americans are pink and indeed only Arabs can be considered white. ${ }^{19}$ There are multiple whitening creams, lotions and pills in local shops and staying out of the sun is one of the women's national obsessions. The black abaya and veil, together with spending the majority of the day indoors, help women to stay perfectly pale. ${ }^{20}$

The situation of sons and daughters of non-Saudi immigrants from Africa, born in Saudi, and of the mixed-race children of Saudi women married to non-Saudis (which is unusual but may happen), leave thousands of citizens of the country without Saudi nationality with many social and legal implications. ${ }^{21}$ This creates an "under-caste" of people not entitled to state care.

Stuck in the lowest caste of the lower class, illegal immigrants are at the bottom of the Saudi social stratification system. This often leads to them living in appalling conditions and becoming a generation of beggars. One rung higher are the migrant workers from undeveloped countries. In their visas and work permits they are classed as third country nationals and are treated much less favourably than second country nationals (high level specialists from western countries). This lowest strata also have subdivisions with Saudis rating Indian workers the highest, as they believe they are the most qualified, have better language skills and the best work ethic. There are racist stereotypes of Filipino, Bangladeshi, Sri Lankan and Pakistani manual labourers. First of all, there is often no distinction between nationalities and all manual foreign labour is considered an under-caste. Surprisingly, this is true regardless of religion. Discrimination can be observed in the way the legal process works in Saudi. In a road traffic incident, the non-Saudi driver is deemed guilty even if objectively he was not. If he had not come to Saudi, the accident would not have taken place, therefore he is to be blamed. There is a visible hierarchy: a Western man will be found guilty when colliding with a Saudi but not guilty if he collides with a third country national. In most criminal cases, third country nationals are kept in "lower standard" prisons and face more difficulty with access to

18 M. Al-Rasheed, 'Modernizing Authoritarian Rule in Saudi Arabia', Contemporary Arab Affairs, Vol. 2, No. 4 (2009), pp. 587-601, at <http://dx.doi.org/10.1080/17550910903244976>.

19 A. Odrowąż-Coates, Fatamorgana..., p. 214.

20 However, this creates vitamin D deficiency in Saudi women causing some considerable health implications. Cf. M.Y. Elsammak et al., 'High Prevalence of Vitamin D Deficiency in the Sunny Eastern Region of Saudi Arabia: a Hospital-Based Study', Eastern Mediterranean Health Journal, Vol. 17, No. 4 (2011); or A.M. Siddiqui, H.Z. Kamfar, 'Prevalence of Vitamin D Deficiency Rickets in Adolescent School Girls in Western Region, Saudi Arabia', Saudi Medical Journal, Vol. 28, No. 3 (2007), pp. 441-444.

$21 \quad$ R. Lacey, Inside the Kingdom... 
legal help, or contact with their embassy. The majority of death penalties in Saudi are given to third country nationals. ${ }^{22}$

A stereotype of Westerners as promiscuous and sexually deviant is perpetuated in local media. The author of this paper has personally watched an interview with a Saudi scholar who claimed that women in the West not only marry other women but also domestic animals. On a different occasion a university professor claimed that an average female American student has about 400 sexual partners in her years of degree study. ${ }^{23}$ The image of third country nationals as uncivilized, savage and worthless, due to the poverty in their country, helps to justify the "charitable actions" of paying a poor family for the services of one of their sons or daughters to take as a servant to the KSA. This is seen as a good deed, helping his starving family. In consequence, the "buyer" may feel he owns the male or female servant and can do anything with them, including punishment by death. There are many ongoing cases of migrant workers' abuse. ${ }^{24}$ The Saudi system of exit visas is one of the factors to blame for this situation. Once in the country, a worker's passport is removed from them and they need permission from their employer to be granted an exit visa. ${ }^{25}$ The removal of an employee's passport has recently been outlawed, but the practice is widespread.

Race and religious divisions are enforced through the national education system. ${ }^{26}$ As already demonstrated in author's previous article on Saudi Arabia, ${ }^{27}$ some of the passages used in the school text books, regarding non Muslims, were extremely racist and divisive.

Table 1. Foreign labour

\begin{tabular}{|c|c|c|c|c|c|}
\hline Country & Australia & Canada & Irland & $\begin{array}{c}\text { United } \\
\text { Kingdom }\end{array}$ & $\begin{array}{c}\text { Saudi } \\
\text { Arabia }\end{array}$ \\
\hline $\begin{array}{c}\text { Foreign labour as a per- } \\
\text { centage of all employed }\end{array}$ & $25 \%$ & $20 \%$ & $5 \%$ & $4 \%$ & $55 \%$ \\
\hline
\end{tabular}

Sources: UNESCO (www.uis.unesco.org); Booz \& Company Ideation Center analysis 2004.

22 S. Marchand, Arabie Saoudite...

23 J. Al-Din Ibrahim, 'Interview on channel KSA 2', May 2011, similar to Egyptian example at <http:// www.memritv.org/clip/en/2755.htm>, 9 March 2013.

24 M. Prokop, 'The War of Ideas...'; Esra’a (Bahrain), 'Migrant Workers throughout the Middle East Experience Frequent Abuse', Mideast Youth, 15 September 2011, at <http://www.mideastyouth. com/2011/09/15/migrant-workers-throughout-the-middle-east-experience-frequent-abuse/>; and A. Haddadi, 'Kenyan Graduates Trafficked to Saudi Arabia, UAE, Qatar and Kuwait by Embassy Staff', International Business Times, 26 March 2012, at <http://www.ibtimes.co.uk/articles/319444/20120326/ embassy-staff-help-human-trafficking-cartel-send.htm>; J. Edep, '10 Pinoys Caught Fishing Illegally in Saudi Seek Help', GMA News, 5 August 2011, at <http://www.gmanetwork.com/news/story/228532/ pinoyabroad/10-pinoys-caught-fishing-illegally-in-saudi-seek-help>, 9 March 2013.

25 P. Handley, 'Under a Bridge, Migrant Workers in Saudi Arabia Wait to Get Arrested', The Telegraph, 5 November 2009, at <http://www.telegraph.co.uk/expat/expatnews/6507960/Under-a-bridge-migrant-workers-in-Saudi-Arabia-wait-to-get-arrested.html>, 9 March 2013.

26 R. Lacey, Inside the Kingdom...; M. Prokop, 'The War of Ideas...'; S. Marchand, Arabie Saoudite...; Al-Rasheed, Contesting the Saudi State.... and Author's own research observations 2010-2012.

27 A. Odrowąż-Coates, 'Wptyw wahhabistycznego przestania religijnego na program nauczania w Saudyjskich szkotach publicznych', Pedagogika Spoteczna, No. 3 (2012), pp. 47-71. 


\section{WORK ETHICS AND CULTURAL CHALLENGES}

As schools have taught obedience and repetition, prevented imagination, creativity and free thinking, ${ }^{28}$ companies are forced to employ better qualified and more capable foreigners. The high percentage of foreign labour is demonstrated in table 1. This gives a reason to complain to the unemployed of Saudi Arabia. In response to the unemployment and dependency on this imported labour force, the Government has developed a policy of "Saudization" as a way of replacing expatriates with Saudis. However, private companies have already made provision for this change by securing funding in new contracts for one "real" worker from abroad and two unnecessary "ghost" Saudi workers in an effort to keep the numbers of Saudis up and meet Saudization rules. This once again contributes to the enforcement of poor work ethics, where the Saudi employees simply do not have enough tasks or responsibilities to feel the weight of, or attach any importance to their job. This leads to a claim-oriented culture, where Saudi workers expect to be given money for their sheer existence.

Despite the introduction of a grading and penalty system for companies, the "Nitaqat", complete Saudiazation (recently termed "Nationalisation" by the government) of all industries seems to be something far in the future. The climate of keeping a nation happy, by creating unnecessary work places, teaches people harmful work habits which are now strongly embedded in Saudi society and difficult to change. Saudi workers are commonly less efficient, less productive or not interested in their tasks. ${ }^{29}$ They spend a lot of time on maintaining their social life at work. Due to family pressures, with wives and daughters unable to deal with the legal and health systems without male support, men are often forced to deal with family matters in their working time.

The private sector confirms these problems and readily expresses its negative regard for Saudi nationals' work culture. In contrast to the average expatriate's work characteristics, the Saudi employee stands out as lacking in key skills and knowledge. The private sector is adamant about the negative effects of the 1970's oil boom and riches on the Saudi culture and how it is responsible for producing a generation with a disappointing attitude towards work. Saudis, according to many in the private sector, still feel they are above work. ${ }^{30}$ This may explain population figures which show that one third of the Saudi population of 30 million is comprised of non-Saudi nationals ${ }^{31}$ (the figures do not include illegal immigrants).

Due to the negative stereotyping of foreign labourers, working is seen as undesirable and below Saudi citizens. One should be wealthy enough not to have to work.

\footnotetext{
Ibid.

Eadem, 'Gated Community..., pp. 233-249.

M.S. Fakeeh, Saudization as a Solution..., p. 123.

Data obtained from the Ministry of Economy and Planning at <http://www.mep.gov.sa/themes/GoldenCarpet $/$ index.jsp;jsessionid=4A7020FFEF629F127706D7230AA5FB4F.alfa\# 1362817542299>, 9 March 2013.
} 
One should use others to do all the tasks for them. This leads to poor work ethics and encourages laziness. The other problem uncovered by the author's own research, lies with the fear of "losing face." Saudi employees are often caught covering up the truth to save what Italians call "la bella figura." The other issue identified during the interviews and observations was the inability to make a decision. Due to the inherent blame-culture, people are wary of making decisions and try to avoid it whenever possible. The divisive and strict organizational hierarchy, similar to the social class stratification system, makes it impossible to challenge or question a superior's decisions or actions, not to mention an inability to oppose, which may lead to dangerous circumstances.

People's lives are valued in the following manner: Which class is the person from?; How wealthy are they?; How much income does their family spend? Therefore, the compensation in law for the loss of life of a royal would be "a life for a life," the compensation for the loss of life of a Bangladeshi worker would be 3 years of his salary, which is insignificant. There is a poor safety record and unlike in the West, few are concerned about the safety of third country nationals because they are easy and cheap to replace. The author of this paper heard many stories about when safety issues were raised concerning the health or wellbeing of manual workers and a Saudi would say: do not worry, there are plenty of them from where they come from. ${ }^{32}$ One may be pardoned for killing their servant, but if a servant kills a Saudi, who has perhaps abused them, they may be seen as overstepping the need for self-defence and found guilty of murder and condemned to death. ${ }^{33}$ The abuse of maids has been reported on numerous occasions. ${ }^{34}$

Expatriates state that working alongside Saudis is a challenging experience since the nationals regard themselves as superior and this affects their dealings with "the other." Although many expatriates are economically disadvantaged and are desperate for work, they still believe that Saudi Arabia needs them. They view Saudi as a closed culture that has never learned how to deal with anything or anybody outside the borders of their

32 Saudi Arabia, Thousands of Immigrant Workers Die from Exploitation, Torture and Alcoholism', Muslim Debate, at <http://www.muslimsdebate.com/n.php?nid=6506>; and 'Indian Migrant Workers Exploited and Enslaved in Arab Countries', Asia News, 11 August 2011, at <http://www. asianews.it/news-en/Indian-migrant-workers-exploited-and-enslaved-in-Arab-countries-23121. html>, 8 March 2013.

33 'Saudi Arabia: Abused Indonesian Maid Kills Employer in Self-Defense - Gets Beheaded', The Muslin Issue, 7 August 2012, at <http://themuslimissue.wordpress.com/2012/08/07/saudi-arabia-abused-indonesian-maid-kills-employer-in-self-defense-gets-beheaded/>; and J. Burke, 'Maid "Held Hostage” for 14 Years in Saudi Arabia', The Guardian, 22 June 2011, at <http://www.guardian.co.uk/ world/2011/jun/22/maid-held-hostage-saudi-arabia>, 9 March 2013.

34 'Brutally Tortured Maid in Stable Condition in Saudi Hospital, Consulate Official', Jakarta Globe, 16 November 2010, at <http://jakartaglobe.beritasatu.com/archive/brutally-tortured-maid-in-stable-condition-in-saudi-hospital-consulate-official/>; and Graham J., 'Domestic Workers Face Abuse in Saudi Arabia, Human Rights Watch, 8 July 2008, at <http://www.hrw.org/audio/2008/07/07/domestic-workers-face-abuse-saudi-arabia>; 'Saudi Arabia: A Step to Aid Migrant Workers', Human Rights Watch, 10 April 2012, at <http://www.hrw.org/news/2012/04/10/saudi-arabia-step-aid-migrant-workers>, 9 March 2013. 
comfort zone. They give real life examples of how Saudis are unable to respect, appreciate or work with people from other faiths and cultures and other people by name, colour and race. ${ }^{35}$

The work climate is unique, where Saudis work alongside people that they despise, considering them decadent westerners or an "under caste" from poor backgrounds. For foreigners working in the KSA, local customs take a long time to decipher, particularly the body language, which leaves a degree of fear. This is also true for the people of the KSA themselves. Fear is what dictates how people act in public in Saudi Arabia. People may not criticise the king nor the system. People must comply with the strict dress code, local customs and tradition. People are discouraged from posing philosophical questions about their religion or existence. Saudis are hesitant to trust anyone from outside their clan. It is difficult to befriend anyone who is "different." Interclass mixing is unusual and a friendship with a Shia Muslim, or a Christian is not possible. People feel constantly aware of the social order and Sharia laws. ${ }^{36}$ Capital punishment is a tool to control migrants and to protect Saudi public order. It is rarely applied to Saudis. ${ }^{37}$ Mosques are no different in propagating these divisive messages, calling for the unity of all Muslims. In fact they refer only to Saudis and only to Sunnis. The system feels threatened as well. The beneficiaries of the system fear change, exposure to foreign culture and customs, and of giving people a choice. The author believes that fear is the cement of Saudi society.

\section{WESTERN CORPORATE MIGRATION - NEWCOMER'S POINT OF VIEW}

In this hostile environment, the considerable financial rewards found in the KSA may be somewhat appealing to professionals threatened with economic problems in Europe and the possible loss of their current job. Many of the interviewees viewed corporate migration as a transitory solution offering temporary job security, and due to the handsome salaries on offer, a step towards greater financial stability. Others come to Saudi for a short term contract and then become addicted to the lifestyle that high, non-taxable wages have to offer.

Due to the restrictions placed on women, foreign women find it particularly hard to accommodate and comply, therefore only a small percentage accompany their husbands to Saudi Arabia. This, in some cases, leads to the same problems as those facing

35 M.S. Fakeeh, Saudization as a Solution..., pp. 179-178.

36 G. Chamberlain, 'Saudi Arabia's Treatment of Foreign Workers under Fire after Beheading of Sri Lankan Maid', The Guardian, 13 January 2013, at <http://www.guardian.co.uk/world/2013/jan/13/ saudi-arabia-treatment-foreign-workers>, 2 October 2013.

37 Fardah, 'Team to Save Migrant Workers' Lives in Saudi Arabia', Antara News, 15 October 2011, at <http://www.antaranews.com/en/news/76606/team-to-save-migrant-workers-lives-in-saudi-arabia >; A. Ethirajan, 'Saudi Beheading of Eight Bangladesh Workers Condemned', BBC News, 8 October 2011, at <http://www.bbc.co.uk/news/world-south-asia-15228607>, 2 October 2013. 
Polish migrants to EU countries. ${ }^{38}$ The loosening of family bonds, the marital challenge of growing apart, loss of authority and control over children etc. For single western males, it is difficult to meet a single woman or to spend time with her without a marriage certificate. The religious police "mutawa" keeps a watchful eye on the morality of both the indigenous population and the newcomers. Women who accompany their husbands in the transition to the KSA say that they feel like they are on an everlasting luxurious holiday. However, they complain about the necessity to wear an abaya in public and harassment from the mutawa to cover their hair. They are unhappy about the ban on female drivers and sometimes feel frustrated not being able to cater for themselves. Moreover, as many have described it (especially when living in more remote locations and limited to a western compound area), they feel like prisoners and that their routines have become completely institutionalised and this dictates what they can and can not do. Something one is not used to in one's country of origin.

\section{FINAL REMARKS}

The ethnic divisions embedded in the mentality of the average Saudi citizen are a true reflection of the employment practices and labour market distribution in the KSA. One enforces and legitimises the other in the public's perspective. The ethnic labour division has grave political consequences, keeping the country reliant on migrants and using Shari'a to control them and to keep public order, which is set completely on religious credentials. Whilst writing this paper the author could not escape the critical pedagogy ${ }^{39}$ approach to the subject matter. Moreover, the author had to lean towards performance ethnography ${ }^{40}$ that in principle fights against inequality and discrimination.

This makes this paper intentionally judgemental and open to criticism. Due to post colonial sensitivity of race and gender issues, it was not possible to preclude an Eurocentric perspective. However, Universal Human Rights are unquestionable and one cannot ignore that they are regularly breached in Saudi Arabia. Although the Western world sees the abuse of servants, modern day slavery or a lack of health and safety for the manual worker as illegal, Saudis don't, and find many arguments to legitimise their societal order and customs. In their own eyes, Saudi interviewees shared the belief that being

38 B. Walczak, Spoteczne, edukacyjne i wychowawcze konsekwencje migracji rodziców i opiekunów prawnych uczniów szkót podstawowych, gimnazjalnych i ponadgimnazjalnych, Technical Report, Warszawa 2008; and S. Kozak, "Eurosieroctwo - negatywne skutki migracji zarobkowej dla dzieci i ich rodzin w kraju i za granicą' in idem, Patologia eurosieroctwo w Polsce. Skutki migracji zarobkowej dla dzieci i ich rodzin, Warszawa 2010 (Engram).

39 M.E. Jennings, 'Social Theory and Transformation in the Pedagogy of Dr. Huey P. Newton: A Nativist Reclamation of the Critical Ethnographic Project', Educational Foundations, Vol. 13, No. 1 (1999), pp. 77-94.

40 N.K. Denzin, Performance Ethnography. Critical Pedagogy and the Politics of Culture, Thousand Oaks 2003. 
the descendents of the Prophet Mohamed, the guardians of holy places and the self proclaimed most accurate interpreters of the Quran in the Muslim world, they are simply better than any other nation. Internal class divisions are Allah's will and therefore are not to be questioned. Death takes one to paradise and so is not seen as a reason for mourning. In fact, crying at funerals is prohibited and women, due to their sensitivity, are excluded from participation. ${ }^{41}$ The "purchase" of servants from poor countries is perceived as a "charitable act" and a tradition of slavery allows masters to punish or even kill their subordinates ${ }^{42}$ (despite slavery having been officially abolished in the KSA in the 1960s).

These beliefs are maintained by successful isolation from other ideologies and religions and this is reinforced by scholars and the education system. ${ }^{43}$ Schooling is to blame for the need for specialists from abroad, whilst Saudi graduates remain unemployed and saddle the state. The colossal costs ${ }^{44}$ of education may be viewed as wasted, firstly on women who will never work, secondly on men who cannot find a job due to lack of appropriate skills. Together with the considerable expense of attracting a foreign workforce, these factors pose a massive danger to the future economy of Saudi Arabia if the price of oil drops, or if they simply run out of this natural resource. Both ongoing and future reforms pose a difficult political challenge in the religious climate of anti-globalisation and the rejection of Western ideals. ${ }^{45}$

\section{BIBLIOGRAPHY}

Ahmed Q., In the Land of Invisible Women. A Female Doctor's Journey in the Saudi Kingdom, Naperville 2008.

Alangari H., The Struggle for Power in Arabia. Ibn Saud, Hussein and Great Britain, 1914-1924, Reading 1998.

Al-Din Ibrahim J., 'Interview on channel KSA 2', May 2011, similar to Egyptian example at $<$ http://www.memritv.org/clip/en/2755.htm>.

Al-Lheedan A., Higher Education, Political Development and Stability in Saudi Arabia, Ph.D. dissertation, University of Southern California 1994.

Al-Rasheed M., Contesting the Saudi State. Islamic Voices from a New Generation, CambridgeNew York 2007 (Cambridge Middle East Studies, 25).

41 Q. Ahmed, In the Land of Invisible Women. A Female Doctor's Journey in the Saudi Kingdom, Naperville 2008 .

42 Slavery in Islam, BBC documentary, 7 September 2009, at <http://www.bbc.co.uk/religion/religions/islam/history/slavery_1.shtml>, 2 October 2013, Authors own research 2010-2012, 144 interviews with Saudi nationals.

43 A. Odrowąż-Coates, 'The Influence of Religion on Public Confidence in Saudi Arabia' in O. Kozlova, K. Izdebska (eds.), Cultures of Trust, Szczecin 2013, pp. 231-255.

44 N. Maroun et al., How to Succeed at Education Reform. The Case for Saudi Arabia and the Broader GCC Region, Booz \& Company Ideation Center analysis 2008, at <http://www.ideationcenter.com/ media/file/How_to_Succeed_at_Education_Reform_FINAL.pdf $>$.

45 A. Odrowąż-Coates, ‘Gated Community..., pp. 233-249. 
Al-Rasheed M., 'Modernizing Authoritarian Rule in Saudi Arabia', Contemporary Arab Affairs, Vol. 2, No. 4 (2009), at <http://dx.doi.org/10.1080/17550910903244976>.

'Brutally Tortured Maid in Stable Condition in Saudi Hospital, Consulate Official', Jakarta Globe, 16 November 2010, at <http://jakartaglobe.beritasatu.com/archive/brutally-tortured-maid-in-stable-condition-in-saudi-hospital-consulate-official/>.

Burke J., 'Maid "Held Hostage" for 14 Years in Saudi Arabia', The Guardian, 22 June 2011, at <http://www.guardian.co.uk/world/2011/jun/22/maid-held-hostage-saudi-arabia>.

Chamberlain G., 'Saudi Arabia's Treatment of Foreign Workers under Fire after Beheading of Sri Lankan Maid', The Guardian, 13 January 2013, at <http://www.guardian.co.uk/ world/2013/jan/13/saudi-arabia-treatment-foreign-workers $>$.

Chapin Metz H. (ed.), Saudi Arabia. A Country Study, Washington D.C. 1992 (Area Handbook Series, DA pam, 550-51).

Denzin N.K., Performance Ethnography. Critical Pedagogy and the Politics of Culture, Thousand Oaks 2003.

Edep J., '10 Pinoys Caught Fishing Illegally in Saudi Seek Help', GMA News, 5 August 2011, at <http://www.gmanetwork.com/news/story/228532/pinoyabroad/10-pinoys-caught-fishing-illegally-in-saudi-seek-help>.

Elsammak M.Y. et al., 'High Prevalence of Vitamin D Deficiency in the Sunny Eastern Region of Saudi Arabia: a Hospital-Based Study', Eastern Mediterranean Health Journal, Vol. 17, No. 4 (2011).

Esra'a (Bahrain), 'Migrant Workers throughout the Middle East Experience Frequent Abuse', Mideast Youth, 15 September 2011, at <http://www.mideastyouth.com/2011/09/15/ migrant-workers-throughout-the-middle-east-experience-frequent-abuse/ $>$.

Ethirajan A., 'Saudi Beheading of Eight Bangladesh Workers Condemned', BBC News, 8 October 2011, at <http://www.bbc.co.uk/news/world-south-asia-15228607>.

Fakeeh M.S., Saudization as a Solution for Unemployment. The Case of Jeddah Western Region, Doctoral Thesis in Business Administration, University of Glasgow 2009.

Fardah, 'Team to Save Migrant Workers' Lives in Saudi Arabia', Antara News, 15 October 2011, at <http://www.antaranews.com/en/news/76606/team-to-save-migrant-workers-lives-in-saudi-arabia>.

Gilbar G.G., The Middle East Oil Decade and Beyond. Essays in Political Economy, LondonPortland 1997.

Graham J., 'Domestic Workers Face Abuse in Saudi Arabia', Human Rights Watch, 8 July 2008, at <http://www.hrw.org/audio/2008/07/07/domestic-workers-face-abuse-saudi-arabia>.

Habib J.S., 'Wahhabi Origins of the Contemporary Saudi State' in M. Ayoob, H. Kosebalaban (eds.), Religion and Politics in Saudi Arabia. Wabhabism and the State, Boulder 2009.

Haddadi A., 'Kenyan Graduates Trafficked to Saudi Arabia, UAE, Qatar and Kuwait by Embassy Staff', International Business Times, 26 March 2012, at <http://www.ibtimes.co.uk/ articles/319444/20120326/embassy-staff-help-human-trafficking-cartel-send.htm>.

Handley P., 'Under a Bridge, Migrant Workers in Saudi Arabia Wait to Get Arrested', The Telegraph, 5 November 2009, at <http://www.telegraph.co.uk/expat/expatnews/6507960/ Under-a-bridge-migrant-workers-in-Saudi-Arabia-wait-to-get-arrested.html $>$. 
'Indian Migrant Workers Exploited and Enslaved in Arab Countries', Asia News, 11 August 2011, at <http://www.asianews.it/news-en/Indian-migrant-workers-exploited-and-enslaved-in-Arab-countries-23121.html>.

Jennings M.E., 'Social Theory and Transformation in the Pedagogy of Dr. Huey P. Newton: A Nativist Reclamation of the Critical Ethnographic Project', Educational Foundations, Vol. 13, No. 1 (1999).

King Abdullah University of Science and Technology, at <http://www.kaust.edu.sa/ >.

Kozak S., 'Eurosieroctwo - negatywne skutki migracji zarobkowej dla dzieci i ich rodzin w kraju i za granicą' in idem, Patologia eurosieroctwo w Polsce. Skutki migracji zarobkowej dla dzieci i ich rodzin, Warszawa 2010 (Engram).

Lacey R., Inside the Kingdom. Kings, Clericis, Modernists, Terrorists and the Struggle for Saudi Arabia, London 2009.

Marchand S., Arabie Saoudite, la menace, Paris 2003.

Maroun N. et al., How to Succeed at Education Reform. The Case for Saudi Arabia and the Broader GCC Region, Booz \& Company Ideation Center analysis 2008, at <http://www.ideationcenter.com/media/file/How_to_Succeed_at_Education_Reform_FINAL.pdf $>$.

Ministry of Economy and Planning, at <http://www.mep.gov.sa/themes/GoldenCarpet/index.jsp; jsessionid=4A7020FFEF629F127706D7230AA5FB4F.alfa\#1362817542299>.

Odrowąż-Coates A., Fatamorgana saudyjskiejprzestrzeni spoteczno-kulturowej kobiet. Ptynne horyzonty socjalizacji, edukacji i emancypacji, Kraków 2015.

Odrowąż-Coates A., 'Gated Community as a "Soft” and Gendered Total Institution', International Sociology, Vol. 30, No. 3 (2015), at <http://dx.doi.org/10.1177/0268580915578759>.

Odrowąż-Coates A., 'The Influence of Religion on Public Confidence in Saudi Arabia' in O. Kozlova, K. Izdebska (eds.), Cultures of Trust, Szczecin 2013.

Odrowąż-Coates A., 'Wptyw wabhabistycznego przestania religijnego na program nauczania w Saudyjskich szkotach publicznych', Pedagogika Spoteczna, No. 3 (2012).

Okruhlik G., 'Networks of Dissent: Islamism and Reform in Saudi Arabia', Social Science Research Council, at <http://essays.ssrc.org/sept11/essays/okruhlik_text_only.htm>.

Prokop M., 'The War of Ideas: Education in Saudi Arabia' in P. Aarts, G. Nonneman (eds.), Saudi Arabia in the Balance. Political Economy, Society, Foreign Affairs, New York 2006.

Ramady M.A., The Saudi Arabian Economy. Policies, Achievements and Challenges. New York 2005.

Rashid N.I., Shaheen E.I., King Fahd and Saudi Arabia's Great Evolution, Joplin (Mo.) 1987.

'Saudi Arabia: A Step to Aid Migrant Workers', Human Rights Watch, 10 April 2012, at <http://www.hrw.org/news/2012/04/10/saudi-arabia-step-aid-migrant-workers>.

'Saudi Arabia: Abused Indonesian Maid Kills Employer in Self-Defense - Gets Beheaded', The Muslin Issue, 7 August 2012, at <http://themuslimissue.wordpress.com/2012/08/07/ saudi-arabia-abused-indonesian-maid-kills-employer-in-self-defense-gets-beheaded/> .

'Saudi Arabia, Thousands of Immigrant Workers Die from Exploitation, Torture and Alcoholism', Muslim Debate, at <http://www.muslimsdebate.com/n.php?nid=6506>.

Sfakianakis J., 'Banque Saudi Fransi: Saudi Arabia Economics - Employment Quandary', The Gulf Intelligence, 21 February 2011, at <http://www.thegulfintelligence.com/Docs. Viewer/8ad91021-1053-43d7-b8a8-d250151257ab/default.aspx>. 
Siddiqui A.M., Kamfar Z.H., 'Prevalence of Vitamin D Deficiency Rickets in Adolescent School Girls in Western Region, Saudi Arabia', Saudi Medical Journal, Vol. 28, No. 3 (2007). Slavery in Islam, BBC documentary, 7 September 2009, at <http://www.bbc.co.uk/religion/ religions/islam/history/slavery_1.shtml>.

Vassiliev A., The History of Saudi Arabia, London 2000.

Walczak B., Spoteczne, edukacyjne i wychowawcze konsekwencje migracji rodziców i opiekunów prawnych uczniów szkót podstawowych, gimnazjalnych i ponadgimnazjalnych, Technical Report, Warszawa 2008.

Dr Anna ODROWĄŻ-COATES holds a Ph.D. in sociology (2005) and currently works as assistant professor at the Social Pedagogy Department in The M. Grzegorzewska Academy of Special Education, Warsaw. She previously worked for Lincolnshire Police and Lincolnshire Criminal Justice Board (UK). Her main areas of expertise are social inequalities, in particular ethnic and gender issues and the reproduction of social systems through education. 